Article

\title{
Fluorinated Organic Paramagnetic Building Blocks for Cross-Coupling Reactions
}

\author{
Larisa V. Politanskaya ${ }^{1}$, Pavel A. Fedyushin ${ }^{1}$, Tatyana V. Rybalova ${ }^{1}{ }^{\circledR}$, Artem S. Bogomyakov $^{2}{ }^{\mathbb{D}}$, \\ Nargiz B. Asanbaeva ${ }^{1}$ and Evgeny V. Tretyakov ${ }^{1,3, * \mathbb{D}}$ \\ 1 N.N. Vorozhtsov Novosibirsk Institute of Organic Chemistry, 9 Ac. Lavrentiev Avenue, \\ 630090 Novosibirsk, Russia; plv@nioch.nsc.ru (L.V.P.); feduyshin@nioch.nsc.ru (P.A.F.); \\ rybalova@nioch.nsc.ru (T.V.R.); nasanbaeva@nioch.nsc.ru (N.B.A.) \\ 2 International Tomography Center, Siberian Branch of Russian Academy of Sciences, 3a Institutskaya Str., \\ 630090 Novosibirsk, Russia; bus@tomo.nsc.ru \\ 3 N.D. Zelinsky Institute of Organic Chemistry, Leninsky Prospect, 47, 119991 Moscow, Russia \\ * Correspondence: tretyakov@nioch.nsc.ru
}

Academic Editor: Maria João Queiroz

Received: 21 October 2020; Accepted: 18 November 2020; Published: 19 November 2020

check for updates

\begin{abstract}
New stable polyfluorinated nitroxide radicals for use in cross-coupling reactions, namely, $\mathrm{N}$-tert-butyl- $\mathrm{N}$-oxyamino-2,3,5,6-tetrafluoro-4-iodobenzene and $\mathrm{N}$-tert-butyl- $\mathrm{N}$-oxyamino-2,3,5,6tetrafluoro-4-ethynylbenzene, were prepared from perfluoroiodobenzene. The reaction of the polyfluoro derivative with tert-butylamine under autoclaving conditions leading to the formation of $N$-tert-butyl-2,3,5,6-tetrafluoro-4-iodoaniline proved to be the key stage of the whole process. The fluorinated tert-butyl iodophenyl nitroxide was found to form in a solid state via $\mathrm{N}-\mathrm{O} \cdots \mathrm{I}$ halogen bonds, a one-dimensional assembly of the radicals. The acceptor role of the nitroxide group in the halogen bonding changes to a donor role when the nitroxide reacts with $\mathrm{Cu}(\mathrm{hfac})_{2}$. In the last case, zero-dimensional assembly prevails, giving a three-spin complex with axial coordinated nitroxide groups and, as a consequence, causing ferromagnetic intramolecular exchange interactions between $\mathrm{Cu}(\mathrm{II})$ and radical spins.
\end{abstract}

Keywords: stable organic radicals; functionalized nitroxides; tert-butylarylnitroxides; fluoroarenes; aromatic nucleophilic substitution

\section{Introduction}

tert-Butylarylnitroxides and corresponding polynitroxides are an important class of paramagnets that have been actively used in different fields of research. A typical method for the preparation of tert-butylarylnitroxides involves an interaction of an appropriate aromatic organometallic compound with tert-nitrosobutane, thus giving aryl tert-butylhydroxylamine, followed by its oxidation to the target radical product. Less commonly, the oxidation of $\mathrm{N}$-tert-butylanilines is performed to obtain nitroxide radicals $[1,2]$.

Recently, we proposed a new synthetic approach to obtaining functionalized tertbutylphenylnitroxides by sequential substitution of a fluorine atom in polyfluorinated arenes with tert-butylamine or lithium tert-butylamide and oxidation of resultant $N$-tert-butylanilines with meta-chloroperoxybenzoic acid (m-CPBA). This approach has been found to generate nitroxide mono- and diradicals in high yields (Figure 1) [3,4]. Moreover, it turned out that polyfluorinated tert-butylarylnitroxides are much stable than nonfluorinated analogs. Therefore, the nitroxides of this type can serve as paramagnetic building blocks for diverse applications. 

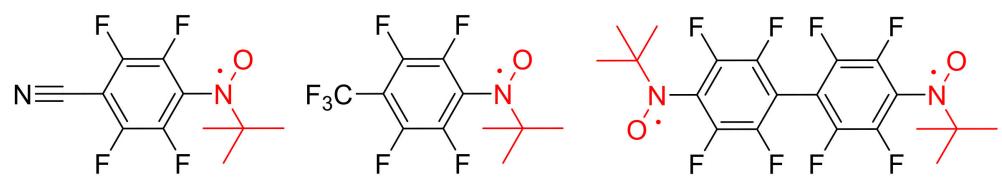

Figure 1. Synthesized polyfluorinated tert-butylarylnitroxides.

In particular, one of the tasks of our current project aimed at obtaining spin-labeled graphene nanostructures is to search for stable paramagnetic blocks suitable for introduction into polycondensed aromatic structures and capable of efficiently injecting spin density into such structures [5-8]. Because the above-mentioned polyfluorinated tert-butylarylnitroxides satisfy all these requirements, within the framework of this work, we studied the possibility of obtaining their iodo and ethynyl derivatives that may be next subjected to the Sonogashira cross-coupling reaction.

\section{Results and Discussion}

Following the newly developed approach, we carried out the reaction of perfluoroiodobenzene with tert-butylamine in chloroform at room temperature (r.t.). As opposed to perfluorotoluene and perfluorobenzonitrile, the iodo derivative did not possess enough reactivity, and the reaction with the amine did not proceed. The use of tert-butylamine under autoclaving conditions at $120{ }^{\circ} \mathrm{C}$ led to the substitution of the fluorine atom in perfluoroiodobenzene and the formation of $\mathrm{N}$-tert-butyl-2,3,5,6-tetrafluoro-4-iodoaniline (1) in a high yield. Formation of other isomeric amines was not detectable (Supplementary Materials). The oxidation of diamine 1 with $m$-CPBA was performed in $\mathrm{CHCl}_{3}$ at r.t. and gave one of the target nitroxide radicals, 4 , in a yield of $\sim 60 \%$ (Scheme 1 ).

4-Iodoaniline 1 was cross-coupled with trimethylsilyl acetylene in $\operatorname{dry} \mathrm{Et}_{3} \mathrm{~N}$ in the presence of $\mathrm{Pd}\left(\mathrm{PPh}_{3}\right)_{2} \mathrm{Cl}_{2}(5 \mathrm{~mol} \%)$ and $\mathrm{CuI}(10 \mathrm{~mol} \%)$ as catalysts. The reaction was carried out at r.t. in a tightly closed Schlenk flask in an argon atmosphere. The process was terminated after the disappearance of ${ }^{19} \mathrm{~F}$ NMR signals belonging to the starting compound to obtain alkynyl derivative 2 with a yield of $\sim 92 \%$. The resulting compound 2 was cleaved by the action of $\mathrm{K}_{2} \mathrm{CO}_{3}$ in $\mathrm{MeOH}$ at r.t., thus producing fluorinated ethynyl-derivative 3 with an almost quantitative yield (Supplementary Materials). At the final stage, amine 3 was oxidized with $m$-CPBA in $\mathrm{CHCl}_{3}$ at r.t. and gave ethynyl-substituted nitroxide 5 as a red oily compound in a yield of $\sim 58 \%$. Both nitroxide radicals 4 and 5 were found to be stable and were purified by thin-layer chromatography (TLC).

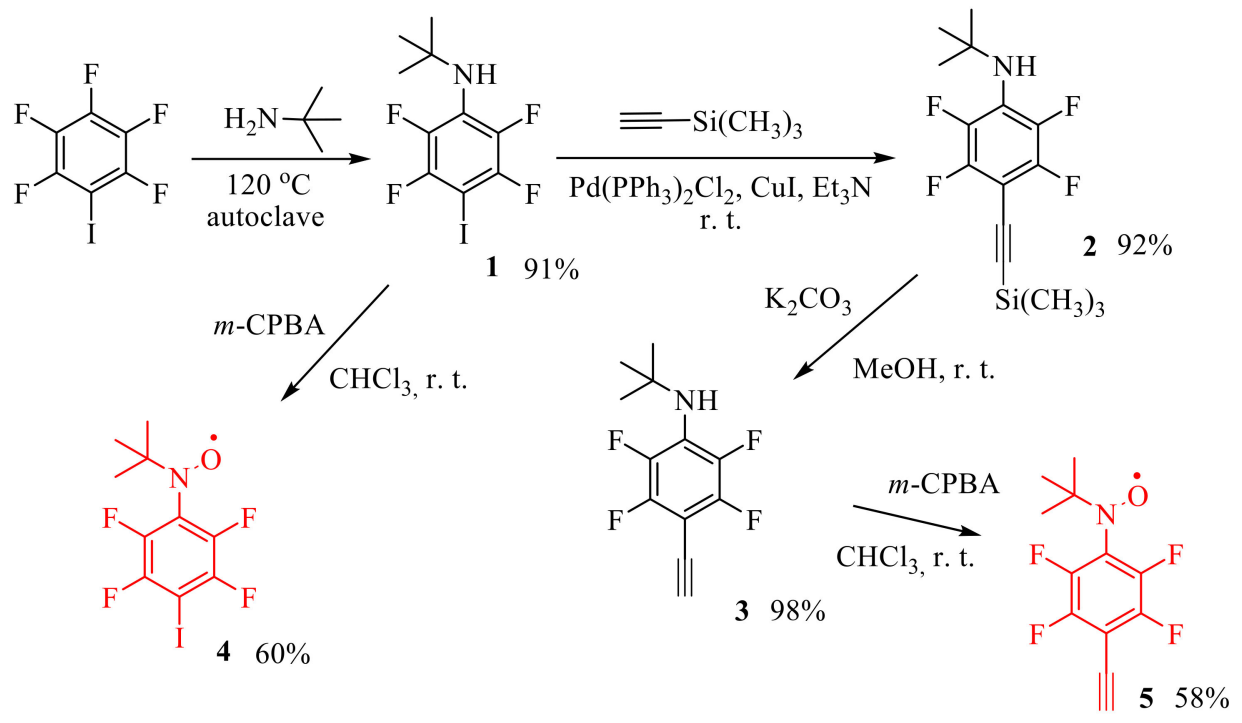

Scheme 1. Synthesis of polyfluorinated tert-butylarylnitroxides 4 and 5 . 
Electron spin resonance (ESR) spectra (Figures 2 and 3) for diluted $\left(\sim 10^{-4} \mathrm{M}\right)$ and oxygen-free toluene solutions of radicals 4 and 5 showed triplet patterns at $g_{\text {iso }}=2.0065$ and $g_{\text {iso }}=2.0064$, respectively. The spectra were simulated with the following sets of parameters: For 4, $\mathrm{A}_{\mathrm{N}}=1.283 \mathrm{mT}$ and $A_{2 F}=0.078 \mathrm{mT}$; for $5, A_{N}=1.278 \mathrm{mT}$. In the case of nitroxide 5, a high-resolution ESR spectrum was recorded to achieve more complex splitting of the central line of its triplet. The spectrum was well simulated, taking into account nine hyperfine structure (hfs) constants for the protons of the tert-butyl group $\left(\mathrm{A}_{\mathrm{H}}=0.022 \mathrm{mT}\right)$, two pairs of hfs constants for the distant fluorine atoms $\left(\mathrm{A}_{\text {Fortho }}=0.089 \mathrm{mT}\right.$; $\left.\mathrm{A}_{\text {Fmeta }}=0.044 \mathrm{mT}\right)$ and one hfs constant for the acetylene proton $\left(\mathrm{A}_{\mathrm{H}}=0.075 \mathrm{mT}\right)$.

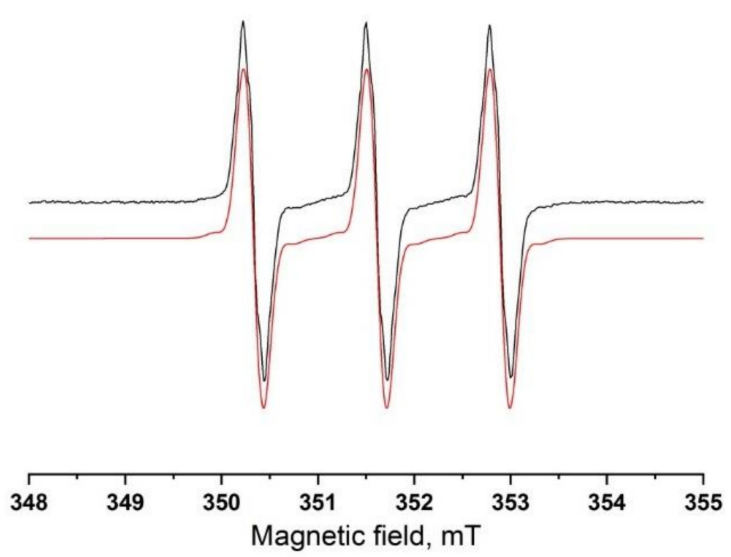

Figure 2. Experimental (black curve) and simulated (red curve) electron spin resonance (ESR) spectra of 4 .

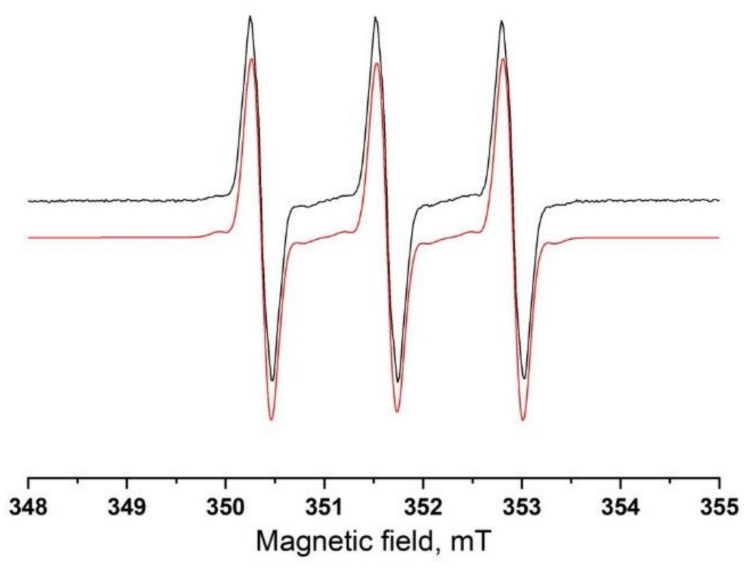

(a)

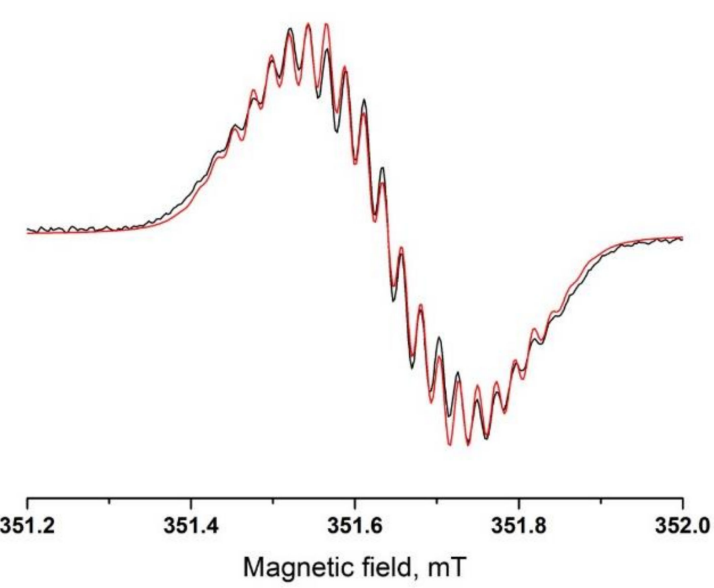

(b)

Figure 3. Experimental (black curves) and simulated (red curves) ESR spectra of 5; (a) the whole spectrum; (b) the central component.

Even though both freshly prepared radicals 4 and $\mathbf{5}$ were red oils, repeated efforts were made to obtain them in a crystalline form. Eventually, by crystallization from a cold $n$-heptane solution, nitroxide radical 4 was isolated as high-quality crystals that allowed to solve its molecular and crystal structure by X-ray diffraction (XRD) analysis (Figure 4). It was revealed that radical 4 crystallizes in the orthorhombic Pbca space group (Table 1). Bond lengths of the tert-butylnitroxide moiety (Table 2) are fully consistent with those of previously described radicals of this family [3]. The nitroxide groups in diradical 4 are twisted at a large angle $\left(\sim 64^{\circ}\right)$ relative to the aromatic ring. The observed twisting is due to, first, steric repulsion between the tert-butyl group and ortho-fluorine atoms and, second, electrostatic 
repulsion of dipoles C-F and N-O. In this regard, the analogous dihedral angle in nonfluorinated tert-butylphenylnitroxides is twofold smaller and has experimental and calculated values of 23-34 [9].

Table 1. XRD data for compounds $4,\left[\mathrm{Cu}(\mathrm{hfac})_{2}(4)_{2}\right]$ and $\left[\mathrm{Cu}(\mathrm{hfac})_{2}(5)\right]$.

\begin{tabular}{|c|c|c|c|}
\hline Compound & 4 & {$\left[\mathrm{Cu}(\mathrm{hfac})_{2}(4)_{2}\right]$} & {$\left[\mathrm{Cu}(\mathrm{hfac})_{2}(5)\right]$} \\
\hline Empirical formula & $\mathrm{C}_{10} \mathrm{H}_{9} \mathrm{~F}_{4} \mathrm{INO}$ & $\mathrm{C}_{30} \mathrm{H}_{20} \mathrm{CuF}_{20} \mathrm{I}_{2} \mathrm{~N}_{2} \mathrm{O}_{6}$ & $\mathrm{C}_{22} \mathrm{H}_{12} \mathrm{CuF}_{16} \mathrm{NO}_{5}$ \\
\hline Formula weight & 362.08 & 1201.82 & 737.87 \\
\hline Crystal system & Orthorhombic & Triclinic & Triclinic \\
\hline Space group & $\mathrm{Pbca}$ & $P^{-1}$ & $P^{-} 1$ \\
\hline Unit cell dimensions $a, \AA$ & $11.5462(4)$ & $10.0763(9)$ & $9.132(1)$ \\
\hline$b, \AA$ & $12.1680(5)$ & $13.784(1)$ & $10.472(1)$ \\
\hline$c, \AA$ & $17.8601(7)$ & $16.009(2)$ & $17.273(2)$ \\
\hline$\alpha,^{\circ}$ & 90 & $96.469(3)$ & $75.370(6)$ \\
\hline$\beta, \circ$ & 90 & $102.396(4)$ & $83.253(6)$ \\
\hline$\gamma,{ }^{\circ}$ & 90 & 104.941(3) & $65.505(5)$ \\
\hline Volume, $\AA^{3}$ & $2509.2(2)$ & $2064.7(3)$ & $1454.3(3)$ \\
\hline Z & 8 & 2 & 2 \\
\hline$F(000)$ & 1384 & 1154 & 728 \\
\hline Density (calcd.), $\mathrm{Mg} \cdot \mathrm{m}^{-3}$ & 1.917 & 1.933 & 1.685 \\
\hline Abs. coefficient, $\mathrm{mm}^{-1}$ & 2.59 & 2.16 & 0.89 \\
\hline Crystal size, mm & $0.90 \times 0.30 \times 0.10$ & $0.30 \times 0.15 \times 0.01$ & $0.25 \times 0.24 \times 0.14$ \\
\hline$T_{\min }, T_{\max }$ & $0.544,0.862$ & $0.722,0.862$ & $0.825,0.928$ \\
\hline Reflections collected & 28215 & 34134 & 28365 \\
\hline Independent reflections $\left[R_{\text {int }}\right]$ & 3516 & 7322 & 5688 \\
\hline Reflections observed $(\mathrm{I}>2 \sigma(\mathrm{I}))$ & 2741 & 3850 & 2856 \\
\hline$R_{\text {int }}$ & 0.048 & 0.089 & 0.074 \\
\hline$\theta$ range for data collection $\left(^{\circ}\right)$ & $2.3-30.4$ & $1.6-25.2$ & $2.194-26.088$ \\
\hline Range of $h$, & $-13 \rightarrow 16$ & $-12 \rightarrow 11$ & $-11 \rightarrow 11$ \\
\hline$k$ & $-16 \rightarrow 16$ & $-16 \rightarrow 16$ & $-12 \rightarrow 12$ \\
\hline$l$ & $-23 \rightarrow 24$ & $-19 \rightarrow 18$ & $-21 \rightarrow 21$ \\
\hline Completeness to $\theta 50^{\circ}(\%)$ & 100 & 99.1 & 99.7 \\
\hline Data/restraints/parameters & $3516 / 0 / 157$ & $7322 / 0 / 553$ & $5688 / 6 / 503$ \\
\hline Final $R\left[F^{2}>2 \sigma\left(F^{2}\right)\right]$ & 0.040 & 0.062 & 0.087 \\
\hline Final $w R\left(F^{2}\right)$ (all data) & 0.115 & 0.173 & 0.324 \\
\hline Goodness-of-fit on $F^{2}$ & 1.03 & 1.01 & 1.05 \\
\hline Largest diff. peak/hole, e $\cdot \AA^{-3}$ & $1.44,-1.12$ & $0.71,-0.64$ & $0.64,-0.56$ \\
\hline
\end{tabular}

Table 2. Selected geometrical parameters for 4 and $\left[\mathrm{Cu}(\mathrm{hfac})_{2}(4)_{2}\right]$ (two independent molecules).

\begin{tabular}{|c|c|c|c|}
\hline Compound & 4 & {$\left[\mathrm{Cu}(\mathrm{hfac})_{2}(4)_{2}\right]$} & {$\left[\mathrm{Cu}(\mathrm{hfac})_{2}(4)_{2}\right]^{\prime}$} \\
\hline \multicolumn{4}{|c|}{ Bond lengths, $\AA$} \\
\hline Cu1-O1 & - & $2.401(8)$ & $2.380(7)$ \\
\hline $\mathrm{Cu} 1-\mathrm{O} 2$ & - & $1.933(6)$ & $1.954(6)$ \\
\hline $\mathrm{Cu} 1-\mathrm{O} 3$ & - & $1.955(6)$ & $1.954(5)$ \\
\hline C4-I1 & $2.079(4)$ & $2.062(9)$ & $2.060(8)$ \\
\hline N1-O1 & $1.278(4)$ & $1.29(1)$ & $1.283(9)$ \\
\hline $\mathrm{N} 1-\mathrm{C} 1$ & $1.428(4)$ & $1.43(1)$ & 1.41(1) \\
\hline $\mathrm{N} 1-\mathrm{C} 7$ & $1.493(5)$ & $1.47(1)$ & $1.50(1)$ \\
\hline \multicolumn{4}{|c|}{ Bond angles, ${ }^{\circ}$} \\
\hline $\mathrm{O} 2-\mathrm{Cu} 1-\mathrm{O} 1$ & - & $95.7(2)$ & $98.6(2)$ \\
\hline O3-Cu1-O1 & - & $91.5(3)$ & $91.2(2)$ \\
\hline $\mathrm{O} 2-\mathrm{Cu} 1-\mathrm{O} 3$ & - & $92.3(2)$ & $92.3(2)$ \\
\hline O1-N1-C1 & $115.7(3)$ & $115.8(7)$ & $115.9(6)$ \\
\hline O1-N1-C7 & $118.0(3)$ & 117.2(7) & $116.8(6)$ \\
\hline C1-N1-C7 & $125.3(3)$ & 125.7(7) & $126.4(6)$ \\
\hline
\end{tabular}


The X-ray analysis revealed an assembly of radicals 4 into zigzag chains via halogen bonds between the nitroxide oxygen and iodine atom (Figure $4 b, c)$. If we consider so-called conjugated nitroxides [2], there are very few cases when halogen bonding induces one-dimensional self- or supra-organization of paramagnetic species. Moreover, the halogen bonding with the participation of an iodine atom has been described only for the family of nitronyl nitroxides [10-13]. For tert-butylphenylnitroxides, this type of halogen bonding was shown for the first time. In addition, the halogen bonds observed in nitroxide 4 are very strong, as indicated by the short I1 ‥ O1 distance $(2.967 \AA,>15 \%$ shorter than the sum of van der Waals radii of $\mathrm{O}$ and I [14]) and almost linear C-I . . O angles $\left(\sim 164^{\circ}\right)$. The N-O (1.278(4) $\AA$ ) bond distance is typical of nitronyl nitroxide moieties, indicating that the presence of the halogen bond has little impact on electronic properties of the free radicals. This is a consequence of the essentially electrostatic nature of the halogen bond interaction.

(a)

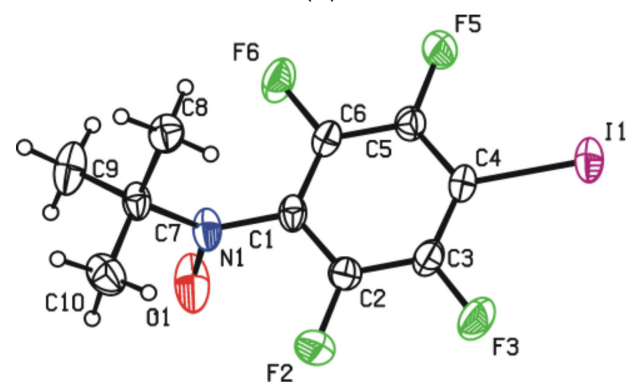

(b)

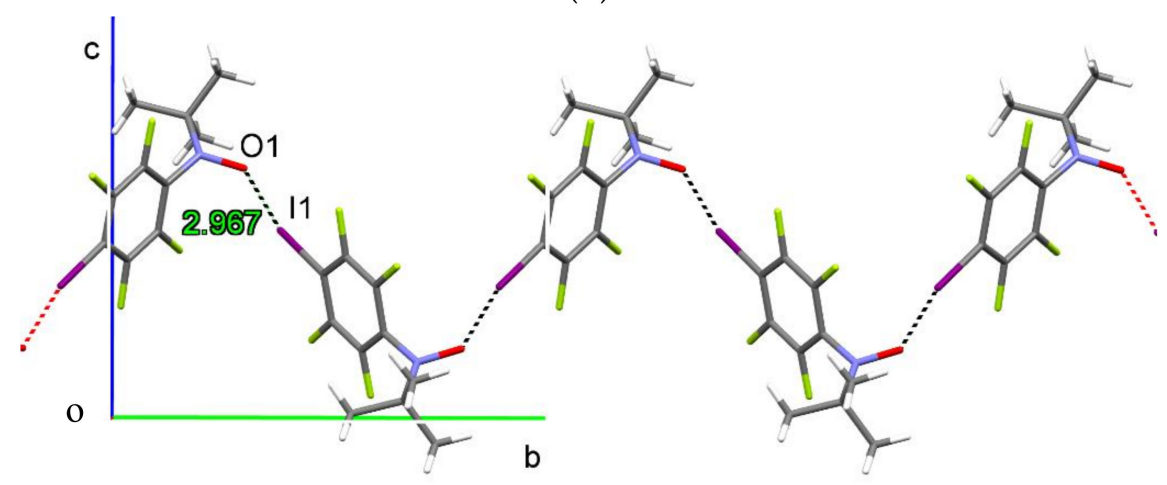

(c)

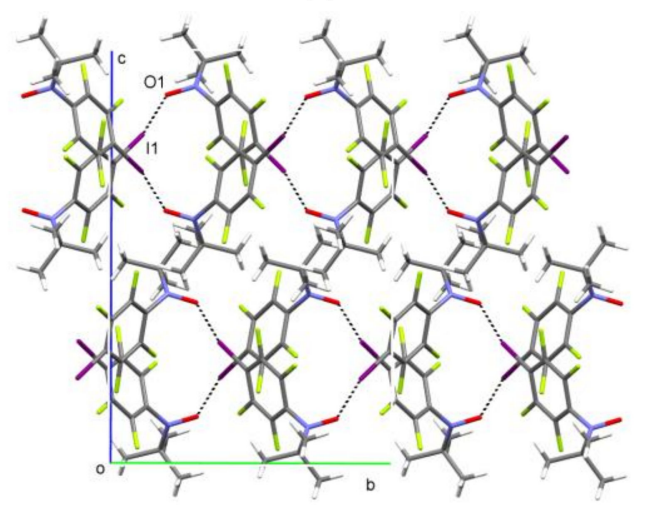

Figure 4. Molecular structure (a) and fragments of crystal structure $(\mathbf{b}, \mathbf{c})$ of nitroxide radical 4 (the thermal ellipsoids are drawn at the $30 \%$ probability level).

An interaction of half an equivalent of bis(hexafluoroacetylacetonato)copper(II) (abbreviated as $\mathrm{Cu}(\mathrm{hfac})_{2}$ ) with radical 4 in $\mathrm{CHCl}_{3}$ gave rise to the $\left[\mathrm{Cu}(\mathrm{hfac})_{2}(4)_{2}\right]$ complex (Supplementary Materials). Its recrystallization from $n$-hexane generated well-shaped crystals suitable for X-ray analysis. If an 
equivalent amount of $\mathrm{Cu}(\mathrm{hfac})_{2}$ was used in the reaction, complex $\left[\mathrm{Cu}(\mathrm{hfac})_{2}(4)_{2}\right]$ also formed along with the crystallization of excess complex $\mathrm{Cu}(\mathrm{hfac})_{2}$. Attempts to prepare a similar complex with nitroxide 5 every time led to the formation of dense intergrowths of crystals of complex [Cu(hfac) $\left.{ }_{2}(5)\right]$. Due to the low quality of the crystals, the structure of the complex was solved with $R$-factor $8.76 \%$ and is considered a tentative result here.

According to XRD analysis, coordination compound $\left[\mathrm{Cu}(\mathrm{hfac})_{2}(4)_{2}\right]$ crystallizes in the triclinic crystal system (space group $P$-1) with two independent molecules per asymmetric unit, as shown in Figure 5a. In the distorted octahedron around the copper ion, two $\mathrm{O}_{\mathrm{NO}}$ atoms occupy axial positions with $d_{\mathrm{Cu}-\mathrm{O}}=2.380$ and $2.400 \AA$ in the independent molecules. Equatorial $\mathrm{Cu}-\mathrm{O}_{\mathrm{hfac}}$ distances in both molecules are in the range of 1.933 to $1.955 \AA$ (Table 2).

In the crystal structure of $\left[\mathrm{Cu}(\mathrm{hfac})_{2}(4)_{2}\right]$, the independent molecules are bound via two van der Waals interactions of the C-F $\cdots \mathrm{C}_{\mathrm{Ph}}$ type (contacts $\mathrm{i}$ and ii). One of the fluorine atoms attached to the aromatic cycle engages in an intermolecular contact (iii) with the $\mathrm{H}$ atoms of the tert-butyl group, thereby binding the dimers into a layer (Figure $5 b$ ).

(a)

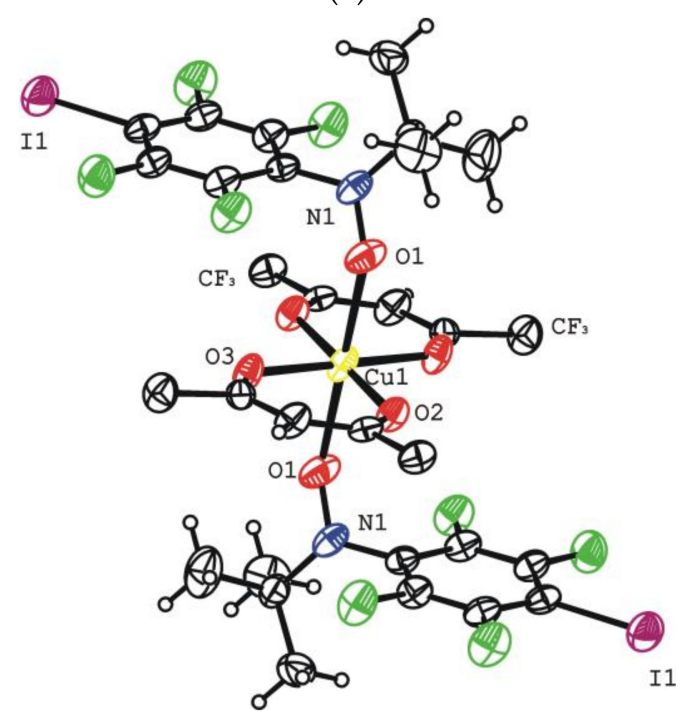

(b)

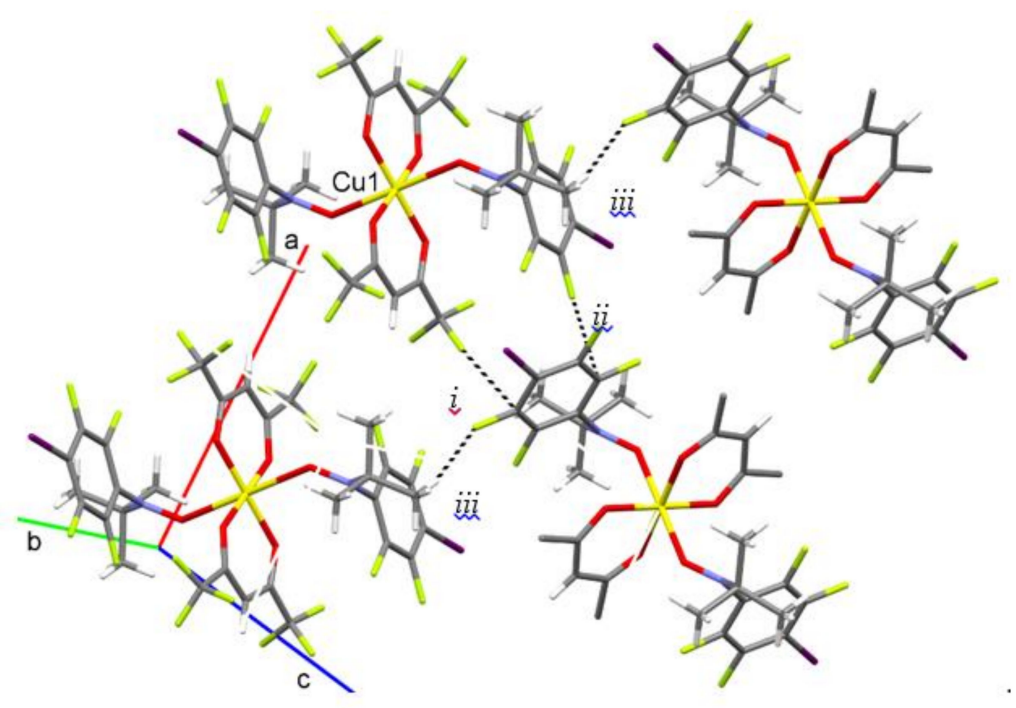

Figure 5. Molecular structure ((a) one of the independent molecules) and fragments of crystal structure (b) of the $\left[\mathrm{Cu}(\mathrm{hfac})_{2}(4)_{2}\right]$ complex (the thermal ellipsoids are drawn at the $30 \%$ probability level). 
Temperature dependences of the effective magnetic moment $\left(\mu_{\mathrm{eff}}\right)$ and inverse magnetic susceptibility $(1 / \chi)$ for complex $\left[\mathrm{Cu}(\mathrm{hfac})_{2}(4)_{2}\right]$ are shown in Figure 6 . The $\mu_{\text {eff }}$ value is $3.17 \mu_{\mathrm{B}}$ at $300 \mathrm{~K}$ and increases with decreasing temperature to $3.55 \mu_{\mathrm{B}}$ at $4 \mathrm{~K}$. The $1 / \chi(T)$ dependence is linear in the temperature range $100-300 \mathrm{~K}$ and obeys the Curie-Weiss law with best-fit values $C=1.218 \pm 0.002 \mathrm{~K} \cdot \mathrm{cm}^{3} / \mathrm{mol}$ and $\theta=9.1 \pm 0.3 \mathrm{~K}$. The $\mu_{\text {eff }}$ value at $300 \mathrm{~K}$ and Curie constant $C$ are in good agreement with theoretical spin-only values of $3.00 \mu_{\mathrm{B}}$ and $1.125 \mathrm{~K} \cdot \mathrm{cm}^{3} / \mathrm{mol}$ for three paramagnetic centers: Two nitroxides and one $\mathrm{Cu}(\mathrm{II})$ ion. The increase in $\mu_{\text {eff }}$ with decreasing temperature and positive Weiss constant $\theta$ indicate the domination of ferromagnetic exchange interactions between spins of paramagnetic centers. An analysis of experimental $\mu_{\text {eff }}(T)$ dependences was performed via a model of a three-spin exchange cluster (spin Hamiltonian $H=-2 J_{C u-R} \times\left(S_{R 1} S_{C u}+S_{C u} S_{R 2}\right)-2 J_{R-R} \times S_{R 1} S_{R 2}$ ), taking into account intermolecular exchange interactions $z J^{\prime}$ in the mean field approximation. Best-fit values of $\mathrm{g}_{\mathrm{Cu}}$ and exchange interaction parameters $J_{C u-R}, J_{R-R}$ and $z J^{\prime}$ are $2.21,15.9 \mathrm{~cm}^{-1},-8.7 \mathrm{~cm}^{-1}$ and $0.15 \mathrm{~cm}^{-1}$, respectively. g-Factors for the nitroxides were fixed at $g_{R}=2$ to avoid overparametrization. The observed ferromagnetic exchange interactions between the unpaired electrons in $\left[\mathrm{Cu}(\mathrm{hfac})_{2}(4)_{2}\right]$ are consistent with the XRD data on the axial coordination of the nitroxide groups to the $\mathrm{Cu}^{2+}$ ion [15-18].

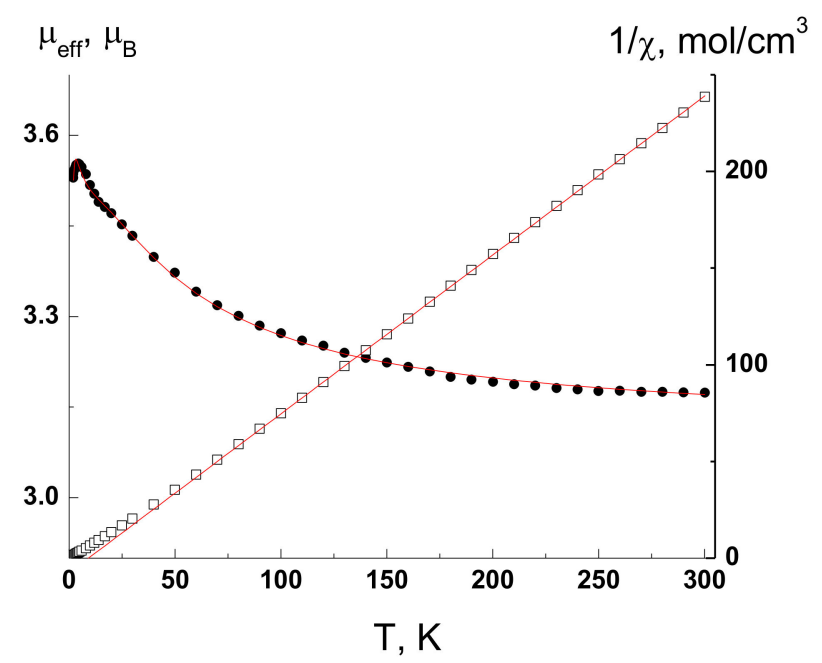

Figure 6. The $\mu_{\text {eff }}(T)(\bullet)$ and $1 / \chi(T)(\square)$ dependences for the $\left[\mathrm{Cu}(\mathrm{hfac})_{2}(4)_{2}\right]$ complex (solid curves are theoretical ones).

\section{Conclusions}

The development of the chemistry of nitroxides opens up new areas of their practical application. Recently, we devised a new synthetic approach to functionalized tert-butylphenylnitroxides via substitution of a fluorine atom in polyfluorinated arenes by tert-butylamine with subsequent oxidation of the obtained $N$-tert-butylanilines with $m$-CPBA [3]. With highly activated polyfluorinated compounds, the substitution reaction proceeds smoothly, with the formation of the corresponding aniline. In the case of less activated polyfluorinated aromatics, we proposed the use of lithium tert-butylamide, which allowed, for example, to synthesize a necessary diamine precursor for the $N, N^{\prime}$-(perfluorobiphenyl-4,4'-diyl)bis( $N$-tert-butyl- $N$-oxyamine) diradical [4]. In the present work, we employed the third version of the reaction, namely, the process was carried out in an autoclave at $120^{\circ} \mathrm{C}$, using tert-butylamine both as a reagent and a solvent. Under these conditions, the reaction of perfluoroiodobenzene with tert-butylamine proceeded regioselectively and gave $\mathrm{N}$-tert-butyl-2,3,5,6-tetrafluoro-4-iodoaniline in high yields. The obtained iodo derivative was converted via a multistep procedure into an ethynyl-substituted aryl nitroxide, which was oxidized into the corresponding tert-butylphenylnitroxide. The latter radical crystalizes with the formation of the structure in which free radicals are bound into one-dimensional chains by relatively strong halogen 
bonds N-O -..I. If upon the formation of the halogen bond the nitroxide group acts as an acceptor, then in the reaction with $\mathrm{Cu}(\mathrm{hfac})_{2}$ it becomes an electron pair donor. The reaction produces a molecular complex of 1:2 composition with axial coordination of the paramagnetic ligands. The result of such coordination gives rise to ferromagnetic intramolecular exchange interactions between $\mathrm{Cu}$ (II) and radical spins.

Both synthesized nitroxides, $N$-tert-butyl-N-oxyamino-2,3,5,6-tetrafluoro-4-iodobenzene and $N$-tert-butyl-N-oxyamino-2,3,5,6-tetrafluoro-4-ethynylbenzene, represent stable paramagnetic building blocks for the Sonogashira cross-coupling reaction. This reaction is being evaluated for the synthesis of functional paramagnets with potential application in the fields of molecular magnetism and spintronics. In particular, in the course of preliminary experiments, it was shown that the paramagnetic iodo derivative can be successfully used to introduce a spin-bearing group into the planar hexabenzocoronene backbone.

\section{Materials and Methods}

\subsection{Materials and Measurements}

$\mathrm{Cu}(\mathrm{hfac})_{2}$ was prepared according to previously described procedures [19]; before use, the $\mathrm{Cu}(\mathrm{hfac})_{2}$ complex was sublimated and stored in a desiccator charged with $\mathrm{NaOH}$. The starting materials were obtained from commercial sources (Merck KGaA, Darmstadt, Germany) and were used without further purification. All solvents were purified according to standard procedures. Preparative TLC was performed on Merck precoated silica gel 60 PF254 containing gypsum. The visualization of developed chromatograms was performed by means of UV light.

NMR spectra were recorded on Bruker Avance-300 (300.13 MHz for ${ }^{1} \mathrm{H}$ and $282.37 \mathrm{MHz}$ for ${ }^{19} \mathrm{~F}$ ), Avance-400 (400.13 MHz for ${ }^{1} \mathrm{H}$ and $100.62 \mathrm{MHz}$ for $\left.{ }^{13} \mathrm{C}\right)$ and DRX-500 (500.13 MHz for ${ }^{1} \mathrm{H}, 125.76 \mathrm{MHz}$ for ${ }^{13} \mathrm{C}$ ) spectrometers (Bruker Corporation, Billerica, MA, USA). $\mathrm{CDCl}_{3}$ served as a solvent, with residual $\mathrm{CHCl}_{3}\left(\delta_{\mathrm{H}}=7.26, \delta_{\mathrm{C}}=77.0\right)$ acting as an internal standard; $\mathrm{C}_{6} \mathrm{~F}_{6}\left(\delta_{\mathrm{F}}=163.0\right)$ was used as an external reference for recording ${ }^{19} \mathrm{~F}$ NMR spectra. ${ }^{13} \mathrm{C}$ NMR spectra were determined with $\mathrm{C}-\mathrm{H}$ spin decoupling.

Continuous-wave ESR spectra were acquired on a commercial Bruker X Band $(9 \mathrm{GHz})$ spectrometer, Elexsys E 540 (Bruker Corporation, Billerica, MA, USA), at r.t. in dilute $\left(\sim 10^{-4} \mathrm{M}\right)$ toluene solutions degassed by means of repeated freeze-pump-thaw cycles. ESR spectra were recorded with the following settings: Frequency, $9.87 \mathrm{GHz}$; microwave power, $2.0 \mathrm{~mW}$; modulation amplitude, $0.01 \mathrm{mT}$ for radical 4 and $0.005 \mathrm{mT}$ for radical 5; time constant, $20.5 \mathrm{~ms}$; and conversion time, $20 \mathrm{~ms}$. Simulations of solution ESR lines were carried out in the EasySpin software (5.2.28) [20], which is available at http://www.easypin.org.

Masses of molecular ions were determined by high-resolution mass spectrometry (HRMS) on a DFS Thermo Scientific instrument at an ionization energy of $70 \mathrm{eV}$ (Thermo Fisher Scientific, Waltham, MA, USA). Melting points were recorded on a Mettler-Toledo FP81 Thermosystem apparatus (Mettler-Toledo, Greifensee, Switzerland). IR spectra were acquired by means of a Bruker Vector 22 spectrometer in $\mathrm{KBr}$ pellets or thin films (Bruker Optik GmbH in Ettlingen). Elemental analyses were performed on a Carlo Erba 1106 CHN elemental analyzer.

Magnetic susceptibility was measured with a MPMSXL SQUID magnetometer (Quantum Design, San Diego, CA) in the temperature range 2 to $300 \mathrm{~K}$ with a magnetic field of up to $5 \mathrm{kOe}$. Diamagnetic corrections were made via Pascal constants. The effective magnetic moment was calculated as follows: $\mu_{\mathrm{eff}}(T)=\left(\left(3 \mathrm{k} / \mathrm{N}_{\mathrm{A}} \mu_{\mathrm{B}}{ }^{2}\right) \chi \mathrm{T}\right)^{1 / 2} \approx(8 \chi \mathrm{T})^{1 / 2}$. 


\subsection{Synthetic Procedures}

\subsubsection{N-tert-Butyl-2,3,5,6-tetrafluoro-4-iodoaniline (1)}

Pentafluoroiodobenzene $(1.50 \mathrm{~g}, 5.1 \mathrm{mmol})$ and 2-methylpropan-2-amine $(5 \mathrm{~mL})$ were placed into a stainless-steel autoclave (volumetric capacity $50 \mathrm{~mL}$ ). The reaction mixture was stirred at $120{ }^{\circ} \mathrm{C}$ for $90 \mathrm{~h}$. Then, the mixture was allowed to cool down to r.t., placed directly onto a chromatography plate (silica gel) and air-dried. The title product was isolated by TLC with hexane as an eluent $\left(R_{f}=0.65\right)$ in a $91 \%$ yield $\left(1.62 \mathrm{~g}\right.$ ) as colorless oil. IR (thin), $v_{\max }: 3423,2968,2121,2088,1801,1732,1635,1487$, $1460,1396,1369,1288,1228,1203,1130,1088,972,810 \mathrm{~cm}^{-1} ;{ }^{1} \mathrm{H}$ NMR $\left(300 \mathrm{MHz}, \mathrm{CDCl}_{3}\right): \delta=3.46$ (br s, $1 \mathrm{H}, \mathrm{NH}), 1.28\left(\mathrm{~s}, 9 \mathrm{H}, \mathrm{CH}_{3}\right) ;{ }^{13} \mathrm{C} \mathrm{NMR}\left(126 \mathrm{MHz} \mathrm{CDCl}_{3}\right): \delta=147.1$ [dddd, $^{1} J\left(\mathrm{C}^{3}, \mathrm{~F}^{3}\right)=242.3 \mathrm{~Hz},{ }^{2} J$ $\left.\left(\mathrm{C}^{3}, \mathrm{~F}^{2}\right)=15.1 \mathrm{~Hz}, \mathrm{C}^{3}, \mathrm{C}^{5}\right], 140.2\left[\mathrm{ddt},{ }^{1} J\left(\mathrm{C}^{2}, \mathrm{~F}^{2}\right)=243.4 \mathrm{~Hz},{ }^{2} J\left(\mathrm{C}^{2}, \mathrm{~F}^{3}\right)=16.2 \mathrm{~Hz}, \mathrm{C}^{2}, \mathrm{C}^{6}\right], 126.6\left[\mathrm{tt}^{2}{ }^{2} J\right.$ $\left.\left(\mathrm{C}^{1}, \mathrm{~F}^{2}\right)=14.1 \mathrm{~Hz},{ }^{3} J\left(\mathrm{C}^{1}, \mathrm{~F}^{3}\right)=2.4 \mathrm{~Hz}, \mathrm{C}^{1}\right], 60.4\left[\mathrm{t},{ }^{2} J\left(\mathrm{C}^{4}, \mathrm{~F}^{3}\right)={ }^{2} J\left(\mathrm{C}^{4}, \mathrm{~F}^{5}\right)=28.1 \mathrm{~Hz}, \mathrm{C}^{4}\right], 54.5\left(\mathrm{~s}, \mathrm{C}^{7}\right), 30.1$ $\left[\mathrm{t}, J\left(\mathrm{C}^{8}, \mathrm{~F}^{2}\right)=J\left(\mathrm{C}^{8}, \mathrm{~F}^{6}\right)=2.7 \mathrm{~Hz}, \mathrm{C}^{8}\right] ;{ }^{19} \mathrm{~F} \mathrm{NMR}\left(282 \mathrm{MHz}, \mathrm{CDCl}_{3}\right): \delta=-124.1\left(\mathrm{~m}, 2 \mathrm{~F}, \mathrm{~F}^{3}, \mathrm{~F}^{5}\right),-149.9(\mathrm{~m}$, $\left.2 \mathrm{~F}, \mathrm{~F}^{2}, \mathrm{~F}^{6}\right)$; HRMS (EI): $m / z[\mathrm{M}]^{+}$calcd. for $\mathrm{C}_{10} \mathrm{H}_{10} \mathrm{~F}_{4} \mathrm{NI}$ : 346.9789; found 346.9790 .

\subsubsection{N-tert-Butyl-2,3,5,6-tetrafluoro-4-((trimethylsilyl)ethynyl)aniline (2)}

$\mathrm{Pd}\left(\mathrm{PPh}_{3}\right)_{2} \mathrm{Cl}_{2}(50 \mathrm{mg}, 0.07 \mathrm{mmol})$ and $\mathrm{CuI}(27 \mathrm{mg}, 0.144 \mathrm{mmol})$ were added to a stirred solution of iodoaryl 1 (500 mg, $1.44 \mathrm{mmol}$ ) and ethynyltrimethylsilane (282 mg, $2.88 \mathrm{mmol})$ in $\operatorname{dry~}^{2} t_{3} \mathrm{~N}$ $(20 \mathrm{~mL})$ at r.t. in an argon atmosphere. The mixture was stirred at r.t. for $24 \mathrm{~h}$, placed directly onto a chromatographic plate (silica gel) and air-dried. The title product was isolated by TLC with hexane as an eluent $\left(R_{f}=0.80\right)$ in a $92 \%$ yield $(420 \mathrm{mg})$ as colorless oil. IR (thin), $v_{\max }: 3427,2966,2160,1651$, $1500,1471,1435,1252,1230,1203,983,847,762,702,677 \mathrm{~cm}^{-1} ;{ }^{1} \mathrm{H}$ NMR $\left(300 \mathrm{MHz}, \mathrm{CDCl}_{3}\right): \delta=3.34(\mathrm{br}$ $\mathrm{s}, 1 \mathrm{H}, \mathrm{NH}), 1.29\left[\mathrm{~s}, 9 \mathrm{H}, \mathrm{C}\left(\mathrm{CH}_{3}\right)_{3}\right], 0.24\left[\mathrm{~s}, 9 \mathrm{H}, \mathrm{Si}\left(\mathrm{CH}_{3}\right)_{3}\right] ;{ }^{13} \mathrm{C} \mathrm{NMR}\left(100 \mathrm{MHz}, \mathrm{CDCl}_{3}\right): \delta=147.5$ [dddd, $\left.{ }^{1} J\left(\mathrm{C}^{3}, \mathrm{~F}^{3}\right)=249.7 \mathrm{~Hz},{ }^{2} J\left(\mathrm{C}^{3}, \mathrm{~F}^{2}\right)=14.6 \mathrm{~Hz}, \mathrm{C}^{3}, \mathrm{C}^{5}\right], 139.2\left[\mathrm{ddt},{ }^{1} J\left(\mathrm{C}^{2}, \mathrm{~F}^{2}\right)=239.3 \mathrm{~Hz},{ }^{2} J\left(\mathrm{C}^{2}, \mathrm{~F}^{3}\right)=14.6 \mathrm{~Hz}\right.$, $\left.\mathrm{C}^{2}, \mathrm{C}^{6}\right], 127.1\left[\mathrm{tt},{ }^{2} J\left(\mathrm{C}^{1}, \mathrm{~F}^{2}\right)=13.7 \mathrm{~Hz},{ }^{3} J\left(\mathrm{C}^{1}, \mathrm{~F}^{3}\right)=2.6 \mathrm{~Hz}, \mathrm{C}^{1}\right], 105.7\left[\mathrm{t}, J\left(\mathrm{C}^{7}, \mathrm{~F}^{3}\right)=J\left(\mathrm{C}^{7}, \mathrm{~F}^{5}\right)=3.4 \mathrm{~Hz}, \mathrm{C}^{7}\right]$, $94.4\left[\mathrm{tt},{ }^{2} J\left(\mathrm{C}^{4}, \mathrm{~F}^{3}\right)={ }^{2} J\left(\mathrm{C}^{4}, \mathrm{~F}^{5}\right)=18.4 \mathrm{~Hz}, \mathrm{C}^{4}\right], 89.4\left[\mathrm{t}, J\left(\mathrm{C}^{8}, \mathrm{~F}^{5}\right)=J\left(\mathrm{C}^{8}, \mathrm{~F}^{3}\right)=3.9 \mathrm{~Hz}, \mathrm{C}^{8}\right], 54.3\left(\mathrm{~s}, \mathrm{C}^{10}\right), 30.2$ $\left[\mathrm{t}, J\left(\mathrm{C}^{11}, \mathrm{~F}^{2}\right)=J\left(\mathrm{C}^{11}, \mathrm{~F}^{6}\right)=3.0 \mathrm{~Hz}, \mathrm{C}^{11}\right],-0.4\left(\mathrm{~s}, \mathrm{C}^{9}\right) ;{ }^{19} \mathrm{~F} \mathrm{NMR}\left(282 \mathrm{MHz}, \mathrm{CDCl}_{3}\right): \delta=-139.9\left(\mathrm{~m}, 2 \mathrm{~F}, \mathrm{~F}^{3}\right.$, $\left.\mathrm{F}^{5}\right),-154.2\left(\mathrm{~m}, 2 \mathrm{~F}, \mathrm{~F}^{2}, \mathrm{~F}^{6}\right)$; HRMS (EI): $m / z[\mathrm{M}]^{+}$calcd. for $\mathrm{C}_{15} \mathrm{H}_{19} \mathrm{~F}_{4} \mathrm{NSi}$ : 317.1217; found 317.1215.

\subsubsection{N-tert-Butyl-4-ethynyl-2,3,5,6-tetrafluoroaniline (3)}

To a solution of $2(230 \mathrm{mg}, 0.72 \mathrm{mmol})$ in $\mathrm{MeOH}(10 \mathrm{~mL}), \mathrm{K}_{2} \mathrm{CO}_{3}(200 \mathrm{mg}, 1.45 \mathrm{mmol})$ was added. The reaction mixture was stirred at r.t. for $3.5 \mathrm{~h}$, then placed directly onto a chromatographic plate (silica gel) and air-dried. The title product was isolated by TLC with hexane as an eluent $\left(R_{f}=0.50\right)$ in a $98 \%$ yield (174 mg) as colorless oil. IR (thin), $v_{\text {max }}$ : 3426, 3307, 2974, 2875, 2117, 1705, 1651, 1500, 1471, 1433, 1471, 1369, 1303, 1232, 1203, 1172, 1041, 985, 974, 893, 806, 673, 605, $432 \mathrm{~cm}^{-1}$; ${ }^{1} \mathrm{H} \mathrm{NMR}(300 \mathrm{MHz}$, $\left.\mathrm{CDCl}_{3}\right): \delta=3.63($ br s, $1 \mathrm{H}, \mathrm{NH}), 3.45\left(\mathrm{~s}, 1 \mathrm{H}, \mathrm{H}^{8}\right), 1.30\left(\mathrm{t}, 9 \mathrm{H}, \mathrm{C}\left(\mathrm{CH}_{3}\right)_{3}\right) ;{ }^{13} \mathrm{C} \mathrm{NMR}\left(126 \mathrm{MHz}_{2} \mathrm{CDCl}_{3}\right)$ : $\delta=147.9\left[\mathrm{dddd},{ }^{1} J\left(\mathrm{C}^{3}, \mathrm{~F}^{3}\right)=250.2 \mathrm{~Hz},{ }^{2} J\left(\mathrm{C}^{3}, \mathrm{~F}^{2}\right)=14.4 \mathrm{~Hz}, \mathrm{C}^{3}, \mathrm{C}^{5}\right.$ ], $139.0\left[\mathrm{ddt},{ }^{1} J\left(\mathrm{C}^{2}, \mathrm{~F}^{2}\right)=239.1 \mathrm{~Hz},{ }^{2} J\right.$ $\left.\left(\mathrm{C}^{2}, \mathrm{~F}^{3}\right)=14.5 \mathrm{~Hz}, \mathrm{C}^{2}, \mathrm{C}^{6}\right], 127.7\left[\mathrm{tt},{ }^{2} \mathrm{~J}\left(\mathrm{C}^{1}, \mathrm{~F}^{2}\right)=13.5 \mathrm{~Hz},{ }^{3} J\left(\mathrm{C}^{1}, \mathrm{~F}^{3}\right)=2.7 \mathrm{~Hz}, \mathrm{C}^{1}\right], 92.7\left[\mathrm{tt}^{2}{ }^{2} J\left(\mathrm{C}^{4}, \mathrm{~F}^{3}\right)={ }^{2} J\right.$ $\left.\left(\mathrm{C}^{4}, \mathrm{~F}^{5}\right)=18.2 \mathrm{~Hz}, \mathrm{C}^{4}\right], 87.0\left[\mathrm{t}, J\left(\mathrm{C}^{8}, \mathrm{~F}^{5}\right)=J\left(\mathrm{C}^{8}, \mathrm{~F}^{3}\right)=3.4 \mathrm{~Hz}, \mathrm{C}^{8}\right], 69.4\left[\mathrm{t}, J\left(\mathrm{C}^{7}, \mathrm{~F}^{3}\right)=J\left(\mathrm{C}^{7}, \mathrm{~F}^{5}\right)=4.0 \mathrm{~Hz}\right.$, $\left.\mathrm{C}^{7}\right], 54.2\left(\mathrm{~s}, \mathrm{C}^{9}\right), 30.3\left[\mathrm{t}, J\left(\mathrm{C}^{11}, \mathrm{~F}^{2}\right)=J\left(\mathrm{C}^{11}, \mathrm{~F}^{6}\right)=3.1 \mathrm{~Hz}, \mathrm{C}^{10}\right] ;{ }^{19} \mathrm{~F}$ NMR $\left(282 \mathrm{MHz}, \mathrm{CDCl}_{3}\right): \delta=-140.1(\mathrm{~m}$, $\left.2 \mathrm{~F}, \mathrm{~F}^{3}, \mathrm{~F}^{5}\right),-154.2\left(\mathrm{~m}, 2 \mathrm{~F}, \mathrm{~F}^{2}, \mathrm{~F}^{6}\right)$; HRMS (EI): $\mathrm{m} / \mathrm{z}[\mathrm{M}]^{+}$calcd. for $\mathrm{C}_{12} \mathrm{H}_{11} \mathrm{~F}_{4} \mathrm{~N}$ : 245.0822; found 245.0823 .

\subsubsection{N-tert-Butyl-N-oxyamino-2,3,5,6-tetrafluoro-4-iodobenzene (4)}

A solution of $N$-tert-butyl-2,3,5,6-tetrafluoro-4-iodoaniline 1 (0.7 mmol) and $m$-CPBA (1.0 mmol, $172 \mathrm{mg})$ in $\mathrm{CHCl}_{3}(5 \mathrm{~mL})$ was stirred at r.t. for $24 \mathrm{~h}$. Column chromatography $\left(\mathrm{SiO}_{2}\right.$ or $\mathrm{Al}_{2} \mathrm{O}_{3}$ column $3 \times 20 \mathrm{~cm}, \mathrm{CHCl}_{3}$ as an eluent) afforded a red fraction of radical 4 . The solvent was removed under reduced pressure at r.t. to obtain title compound 4 . Red crystals; yield $60 \%$ (150 mg); mp $89.8^{\circ} \mathrm{C}$ (decomp.). IR (KBr), $v_{\max }$ : 2981, 1626, 1483, 1462, 1398, 1350, 1275, 1248, 1196, 970, 800, 773, 721,579 $\mathrm{cm}^{-1}$; UV-Vis (EtOH) $\lambda_{\max } / \mathrm{nm}(\mathrm{lg} \varepsilon): 235$ (3.16), 307 (2.60); HRMS (EI): m/z [M] ${ }^{+}$calcd. for $\mathrm{C}_{10} \mathrm{H}_{9} \mathrm{~F}_{4} \mathrm{NOI}$ 
361.9660; found 361.9662; Anal. calcd. for $\mathrm{C}_{10} \mathrm{H}_{9} \mathrm{~F}_{4} \mathrm{NOI}$ C, 33.17; $\mathrm{H}, 2.51 ; \mathrm{N}, 3.87$. Found: $\mathrm{C}, 33.44 ; \mathrm{H}$, $2.43 ; \mathrm{N}, 3.87$.

\subsubsection{N-tert-Butyl-N-oxyamino-2,3,5,6-tetrafluoro-4-ethynylbenzene (5)}

The compound was obtained through the oxidation of amine 3 in a manner similar to the preparation of nitroxyl 4. Red oil; yield 58\% (105 mg). IR (thin), $v_{\max }: 3305,3257,2983,2943,2123$, 1722, 1680, 1643, 1616, 1491, 1396, 1367, 1304, 1252, 1201, 989, 835, 787, 769, 735, 677, 642, 584, 501 $\mathrm{cm}^{-1}$; UV-Vis (EtOH) $\lambda_{\max } / \mathrm{nm}$ (lg $\varepsilon$ ): 239 (3.11), 249 (3.08), 317 (2.41); HRMS (EI): $\mathrm{m} / z$ [M] ${ }^{+}$calcd. for $\mathrm{C}_{12} \mathrm{H}_{10} \mathrm{~F}_{4} \mathrm{NO}$ : 260.0693; found 260.0691 .

4.2.6. trans-Bis $\left(1,1,1,5,5,5\right.$-hexafluoropentane-2,4-dionato- $\left.\kappa^{2} \mathrm{O}, \mathrm{O}^{\prime}\right)$ bis $\{\mathrm{N}$-tert-butyl- $\mathrm{N}$-oxyamino2,3,5,6-tetrafluoro-4-iodobenzene- $\kappa O\}$ copper(II) ([Cu(hfac) $\left.\left.)_{2}(4)_{2}\right]\right)$

$\mathrm{Cu}(\mathrm{hfac})_{2} \cdot \mathrm{H}_{2} \mathrm{O}(248 \mathrm{mg}, 0.5 \mathrm{mmol})$ was added to a solution of radical $4(362 \mathrm{mg}, 1.0 \mathrm{mmol})$ in $\mathrm{CHCl}_{3}(10 \mathrm{~mL})$. The reaction mixture was stirred for $30 \mathrm{~min}$ and then was incubated at $-15^{\circ} \mathrm{C}$ for $10 \mathrm{~h}$. The solution was filtered and evaporated. The residue was dissolved in $n$-hexane $(5 \mathrm{~mL})$ and the resultant solution was filtered and incubated at $-15^{\circ} \mathrm{C}$ for $10 \mathrm{~h}$ to prepare crystals that were filtered off and air-dried. Brown crystals; yield 78\%; IR (KBr) $\tilde{\mathrm{v}}_{\max }, \mathrm{cm}^{-1}: 3435,3001,2985,1641,1597,1558,1527$, $1485,1400,1354,1261,1207,1149,1107,1030,968,816,798,773,746,723,681,596,581,530$; calcd. for $\mathrm{C}_{30} \mathrm{H}_{20} \mathrm{~N}_{2} \mathrm{CuF}_{20} \mathrm{I}_{2} \mathrm{O}_{6}$ : C 29.98, H 1.68, F, 31.62; N 2.33; found C 30.30, H 1.57, F 31.76, N 2.07.

\subsection{Single-Crystal XRD Analyses}

XRD data were collected at r.t. on a Bruker Kappa Apex II CCD diffractometer with Mo K $\alpha$ radiation $(\lambda=0.71073 \AA$ ) and a graphite monochromator (Table 1). Absorption corrections were applied empirically using $S A D A B S$ programs [21]. The structures were solved by direct methods by means of the SHELXS-97 software suite [22,23] and were refined using the full-matrix least-squares method against all $F^{2}$ in anisotropic approximation (beside the H atoms) using the SHELXL2014/7 software suite [24]. The H atoms' positions were calculated with the riding model. The asymmetric unit of $\left[\mathrm{Cu}(\mathrm{hfac})_{2}(4)_{2}\right]$ contains halves of two independent moieties.

CCDC 2038555, 2,038,556 and 2,039,515 (preliminary data) contain the crystallographic data for $4,\left[\mathrm{Cu}(\mathrm{hfac})_{2}(4)_{2}\right]$ and $\left[\mathrm{Cu}(\mathrm{hfac})_{2}(5)\right]$. These data can be obtained free of charge via http://www.ccdc. cam.ac.uk/cgi-bin/catreq.cgi or from the Cambridge Crystallographic Data Centre, 12 Union Road, Cambridge CB2 1EZ, UK; fax: (+44) 1223336 033; or e-mail: deposit@ccdc.cam.ac.uk.

Supplementary Materials: The Supplementary Materials are available online. NMR spectra and the IR spectrum of $\left[\mathrm{Cu}(\mathrm{hfac})_{2}(4)_{2}\right]$.

Author Contributions: conceptualization, E.V.T.; methodology, L.V.P., P.A.F. and A.S.B.; investigation, L.V.P., P.A.F., T.V.R., A.S.B. and N.B.A.; writing-Original draft preparation, E.V.T.; supervision, E.V.T.; funding acquisition, E.V.T. All authors have read and agreed to the published version of the manuscript.

Funding: This research was funded by the Russian Science Foundation (grant No. 18-13-00173).

Acknowledgments: The authors would like to acknowledge the Multi-Access Chemical Research Center SB RAS for spectral and analytical measurements.

Conflicts of Interest: The authors declare no conflict of interest. The funders had no role in the design of the study; in the collection, analyses or interpretation of the data; in the writing of the manuscript; or in the decision to publish the results. 


\section{References}

1. Hicks, R.G. Stable Radicals: Fundamentals and Applied Aspects of Odd-Electron Compounds; John Wiley and Sons: Chichester, UK, 2010.

2. Tretyakov, E.V.; Ovcharenko, V.I. The chemistry of nitroxide radicals in the molecular design of magnets. Russ. Chem. Rev. 2009, 78, 971-1012. [CrossRef]

3. Tretyakov, E.; Fedyushin, P.; Panteleeva, E.; Gurskaya, L.; Rybalova, T.; Bogomyakov, A.; Zaytseva, E.; Kazantsev, M.; Shundrina, I.; Ovcharenko, V. Aromatic SNF-approach to fluorinated phenyl tert-butyl nitroxides. Molecules 2019, 24, 4493. [CrossRef] [PubMed]

4. Fedyushin, P.; Rybalova, T.; Asanbaeva, N.; Bagryanskaya, E.; Dmitriev, A.; Gritsan, N.; Kazantsev, M.; Tretyakov, E. Synthesis of nitroxide diradical using a new approach. Molecules 2020, 25, 2701. [CrossRef] [PubMed]

5. Slota, M.; Keerthi, A.; Myers, W.K.; Tretyakov, E.; Baumgarten, M.; Ardavan, A.; Sadeghi, H.; Lambert, C.J.; Narita, A.; Müllen, K.; et al. Magnetic edge states and coherent manipulation of graphene nanoribbons. Nature 2018, 557, 691-695. [CrossRef] [PubMed]

6. Stass, D.; Tretyakov, E. Estimation of absolute spin counts in nitronyl nitroxide-bearing graphene nanoribbons. Magnetochemistry 2019, 5, 32. [CrossRef]

7. Morozov, V.; Tretyakov, E. Spin polarization in graphene nanoribbons functionalized with nitroxide. J. Mol. Model. 2019, 25, 58. [CrossRef] [PubMed]

8. Ten, Y.A.; Troshkova, N.M.; Tretyakov, E.V. From spin-labelled fused polyaromatic compounds to magnetically active graphene nanostructures. Russ. Chem. Rev. 2020, 89, 693-712. [CrossRef]

9. Ohshita, J.; Iida, T.; Ohta, N.; Komaguchi, K.; Shiotani, M.; Kunai, A. Synthesis of Phenylnitroxides Bridged by an sp ${ }^{3}$-Linkage. Org. Lett. 2002, 4, 403-406. [CrossRef] [PubMed]

10. Liu, Z.-L.; Song, Y.; Du, C.-F. CCDC 244384, Experimental Crystal Structure Determination. 2014. Available online: https://www.ccdc.cam.ac.uk/structures/search?id=doi:10.5517/cc869c3\&sid=DataCite (accessed on 21 October 2020).

11. Wagner, B.; Gompper, R.; Polborn, K. CSD Communication (Private Communication); CCDC 198532; Department of Chemistry, University of Munich: Munchen, Germany, 2002.

12. Suzuki, S.; Nakamura, F.; Naota, T. A direct synthetic method for (nitronyl nitroxide)-substituted $\pi$-electronic compounds via a palladium-catalyzed cross-coupling reaction with a zinc complex. Mater. Chem. Front. 2018, 2, 591-596. [CrossRef]

13. Espallargas, G.M.; Recuenco, A.; Romero, F.M.; Brammer, L.; Libri, S. One-dimensional organization of free radicals via halogen bonding. CrystEngComm 2012, 14, 6381-6383. [CrossRef]

14. Bondi, A. van der Waals Volumes and Radii. J. Phys. Chem. 1964, 68, 441-451. [CrossRef]

15. Caneschi, A.; Gatteschi, D.; Grand, A.; Laugier, J.; Pardi, L.; Rey, P. Moderate Ferromagnetic Exchange between Copper(II) and a Nitronyl Nitroxide in a Square-Pyramidal Adduct. MO Interpretation of the Mechanism of Exchange in Copper(II)-Nitroxide Complexes. Inorg. Chem. 1988, 27, 1031-1035.

16. Iwahori, F.; Markosyan, A.S.; Inoue, K. Structures and Magnetic Properties of the Complexes Made up by $\mathrm{Cu}(\mathrm{hfac})_{2}$ and Bisnitroxide Radical Derivatives. Mol. Cryst. Liq. Cryst. 2002, 376, 449-454. [CrossRef]

17. Ishimaru, Y.; Kitano, M.; Kumada, H.; Koga, N.; Iwamura, H. Regiospecificity in the Exchange Coupling of the Spins of Copper(II) Ion Coordinated with the Ring Nitrogen Atoms and N-tert-Butylaminoxyl Radical Attached as a Substituent on the Pyridine and N-Phenylimidazole Rings. Inorg. Chem. 1998, 37, 2273-2280. [CrossRef] [PubMed]

18. Field, L.M.; Lahti, P.M.; Palacio, F.; Paduan-Filho, A. Manganese(II) and Copper(II) Hexafluoroacetylacetonate 1:1 Complexes with 5-(4-[N-tert-Butyl-N-aminoxyl]phenyl)pyrimidine: Regiochemical Parity Analysis for Exchange Behavior of Complexes between Radicals and Paramagnetic Cations. J. Am. Chem. Soc. 2003, 125, 10110-10118. [CrossRef] [PubMed]

19. Bertrand, J.A.; Kaplan, R.I. A study of bis(hexafluoroacetylacetonato)copper(II). Inorg. Chem. 1966, 5, $489-491$. [CrossRef]

20. Stoll, S.; Schweiger, A. EasySpin: Simulating cw ESR spectra. Biol. Magn. Reson. 2007, 27, $299-321$.

21. Sheldrick, G.M. SADABS, Program for Area Detector Adsorption Correction; Institute for Inorganic Chemistry, University of Göttingen: Göttingen, Germany, 1996.

22. Sheldrick, G.M. A short history of SHELX. Acta Cryst. A 2008, 64, 112-122. [CrossRef] [PubMed] 
23. Sheldrick, G.M. SHELX-97. Programs for Crystal Structure Analysis (Release 97-2); University of Göttingen: Göttingen, Germany, 1998.

24. Sheldrick, G.M. Crystal structure refinement with SHELXL. Acta Cryst. C 2015, 71, 3-8. [CrossRef] [PubMed]

Sample Availability: Samples of all described compounds are available from the authors.

Publisher's Note: MDPI stays neutral with regard to jurisdictional claims in published maps and institutional affiliations.

(C) 2020 by the authors. Licensee MDPI, Basel, Switzerland. This article is an open access article distributed under the terms and conditions of the Creative Commons Attribution (CC BY) license (http://creativecommons.org/licenses/by/4.0/). 